\title{
PENGARUH PEMBELAJARAN LANGSUNG TERHADAP PEMAHAMAN KONSEP MATRIKS DAN SIKAP ILMIAH MAHASISWA PENDIDIKAN TEKNIK BANGUNAN
}

\author{
Enny Keristiana Sinaga ${ }^{1}$ Syafiatun Siregar ${ }^{2}$, Asri Lubis ${ }^{3}$ \\ 1,2,3Dosen Pengajar Jurusan Pendidikan Teknik Bangunan, Fakultas Teknik, UNIMED, Medan \\ Surel : ennysinagai@unimed.ac.id \\ Diterima : 26 November 2017; Disetujui : 30 November 2017
}

\begin{abstract}
ABSTRAK
Penelitian ini bertujuan untuk mengetahui perbedaan pemahaman konsep matriks dan sikap ilmiah antara mahasiswa yang dibelajarkan dengan model pembelajaran langsung dan model pembelajaran konvensional. Jenis penelitian ini penelitian eksperimen semu dengan rancangan Pretest-Posttest Control Group Design dengan mengambil populasi penelitian mahasiswa Program Studi Pendidikan teknik Bangunan semester 1 Universitas Negeri Medan tahun ajaran 2017/2018. Sampel diambil dengan cara total sampling. Data pemahaman konsep diukur dengan menggunakan tes pemahaman konsep matriks dan sikap ilmiah dengan menggunakan kuesioner. Data yang terkumpul dianalisis dengan menggunakan Manova. Berdasarkan hasil analisis data diperoleh simpulan sebagai berikut: 1) terdapat perbedaan pemahaman konsep matriks antara mahasiswa yang dibelajarkan dengan model pembelajaran langsung dan mahasiswa yang dibelajarkan dengan model pembelajaran konvensional, 2) terdapat perbedaan sikap antara mahasiswa yang dibelajarkan dengan model pembelajaran langsung dan mahasiswa yang dibelajarkan dengan model pembelajaran konvensional, 3) terdapat perbedaan pemahaman konsep matriks dan sikap ilmiah antara mahasiswa yang dibelajarkan dengan model pembelajaran langsung dan mahasiswa yang dibelajarkan dengan model pembelajaran konvensional
\end{abstract}

Kata Kunci : konvensional, pemahaman konsep, pembelajaran langsung, sikap ilmiah

\begin{abstract}
This study aims to determine the differences in understanding the concept of matrix and scientific attitude between students who are taught by direct learning model and conventional learning model. This type of research is a quasi-experimental research with Pretest-Posttest Control Group Design design by taking research population of students of Building Engineering Education Study Program 1st semester of Medan State University of academic year 2017/2018. Samples were taken by total sampling. Data on concept comprehension is measured by using comprehension test of matrix concept and scientific attitude by using questionnaire. The collected data were analyzed using Manova. Based on the results of data analysis obtained conclusions as follows: 1) there is a difference understanding of matrix concepts between students who dibelajarkan with direct learning models and students who dibelajarkan with conventional learning model, 2) there is a difference in attitude between students who are taught by direct learning models and students who dibelajarkan with conventional learning model, 3) there is a difference understanding of matrix concept and scientific attitude between students who dibelajarkan with direct learning models and students who dibelajarkan with conventional learning model
\end{abstract}

Keywords: conventional, conceptual understanding, direct learning, scientific attitude 


\section{Enny Keristiana Sinaga - Syafiatun Siregar - Asri Lubis}

\section{Pendahuluan}

Pada era teknologi informasi dan komunikasi saat ini, ilmu pengetahuan dan teknologi memainkan peranan penting dalam upaya mencapai tujuan dan cita-cita suatu bangsa. Bangsa yang sedang membangun seperti Indonesia, dituntut mampu mengembangkan dan memanfaatkannya sebagai salah satu syarat untuk dapat memacu laju pembangunan di berbagai sekotor bidang. Persaingan untuk memperoleh kesempatan terbaik dalam berbagai hal menjadi semakin ketat saat ini. Oleh karena itu berbagai upaya untuk meningkatkan mutu pendidikan senantiasa dicari dan diteliti melalui kajian berbagai komponen pendidikan.

Salah satu cara agar kualitas sumber daya manusia Indonesia meningkat adalah melakukan inovasi di bidang pendidikan yang berkelanjutan seiring berbagai persoalan, tantangan dan hambatan yang dihadapi di dunia pendidikan. Pembaharuan tersebut dengan peningkatan mutu tenaga pendidik dan kependidikan melalui menempuh program studi lanjut yang relevan, pelatihan dan penataran, penyempurnaan kurikulum dan pengadaan fasilita belajar yang lebih memadai. Tilaar (1999 : 401) menyatakan bahwa peningkatan mutu menciptakan manusia unggul yang memiliki kepribadian yang kuat, yang unggul dan kreatif serta dapat mengabdikan kemampuannya untuk kepentingan dan kemakmuran bersama. Pembaharuan tersebut dilakukan pemerintah termasuk salah satunya pendidikan matematika di sekolah (perguruan tinggi).

Matematika sebagai salah satu ilmu dasar merupakan mata pelajaran yang wajib diajarkan pada semua jenjang pendidikan, baik sekolah dasar, sekolah menengah mupun perguruan tinggi. Cornelius mengatakan bahwa ada banyak alasan tentang perlunya peserta didik belajar matematika, yaitu: 1) merupakan sarana berpikir yang jelas dan logis; 2) sarana memecahkan masalah kehidupan sehari-hari; 3) sarana mengenal pola-pola hubungan dan generalisasi pengalaman; 4) sarana mengembangkan kreativitas; dan 5) sarana untuk meningkatkan kesadaran terhadap perkembangan budaya (dalam Abdurrahman, 2003).

Begitu pentingnya peranan matematika seperti yang diuraikan di atas, seharusnya membuat matematika menjadi salah satu mata pelajaran (mata kuliah) yang menyenangkan dan digemari oleh peserta didik. Namun demikian, tidak dapat dipungkiri lagi bahwa mata kuliah matematika masih merupakan pelajaran yang dianggap sulit, membosankan dan sering menimbulkan masalah dalam belajar. Kondisi ini mengakibatkan mata kuliah matematika tidak disenangi, tidak diperdulikan dan bahkan diabaikan. Hal ini tentunya menimbulkan kesenjangan yang cukup besar antara apa yang diharapkan dari belajar matematika dengan kenyataan yang terjadi di lapangan. Di satu sisi matematika mempunyai peranan penting dalam kehidupan sehari-hari, meningkatkan daya nalar, berpikir logis, sistematis dan kreatif. Di sisi lain banyak peserta didik yang tidak menyenangi mata pelajaran matematika.

Mata Kuliah Matematika pada Program Studi Pendidikan Teknik Bangunan (PTB) terbagi atas Matematika Teknik Dasar pada semester I dan Matematika Teknik pada Semester II. Pada Matematika Teknik Dasar, kompetensi yang diharapkan adalah penguasaan matematika dalam Sistem Persamaan Linear, Determinan, Vektor, Matriks dan Diferensiasi serta penerapannya. Mata kuliah ini kompatibel dengan mata kuliah keteknikan lainnya seperti Mekanika Teknik, Mekanika Tanah, Struktur Beton dan lain-lain. Sedangkan pada Matematika Teknik khusus kompetensi integral dan penerapannya.

Berdasarkan pengamatan dan pengalaman penulis terhadap kegiatan belajar mengajar di Program Studi Pendidikan Teknik Bangunan (PTB) Universitas Negeri Medan, diperoleh informasi bahwa hasil belajar matematika dasar mahasiswa program studi Pendidikan Teknik Bangunan pada tahun ajaran 2016/2017 dengan batas kelulusan minimal C, dari 66 orang mahasiswa, yang memperoleh nilai A sebanyak 8 orang (12,12\%), nilai B sebanyak 26 orang $(39,39 \%)$, nilai C 28 orang $(42 / 42 \%)$ dan nilai $E$ sebanyak 4 orang (6.06\%). Lebih rinci, rendahnya hasil belajar metematika mahasiswa Program Studi PTB Universitas Negeri Medan terlihat dari rata-rata hasil belajar matematika pada materi pokok Sistem Persamaan Linear, Determinan, Matriks, Vektor dan Diferensiasi serta penerapannya pada tahun ajaran 2016/2017 berturut-turut adalah 83.79, 80.57, 69.52, 78.70, dan 72.08. Jika mengacu pada Indeks Prestasi Kumulatif (IPK) yang diharapkan untuk dapat memasuki dunia kerja yang rata-rata minimal IPK 2.75-3.00. Dengan demikian maka mahasiswa harus minimal mendapat nilai $B$ untuk setiap mata kuliah.

Proses pembelajaran mahasiswa terhadap perkuliahan matematika teknik dasar belum menunjukkan terjadinya peningkatan aktivitas, hal ini dapat dilihat dari kesulitan belajar yang 


\section{Pengaruh Pembelajaran Langsung Terhadap Pemahaman Konsep Matriks Dan Sikap Ilmiah Mahasiswa Pendidikan Teknik Bangunan}

dialami mahasiswa dalam kegiatan memperhatikan dan mendengarkan penjelasan dosen, bertanya atau menyatakan pendapat, melakukan pengamatan, diskusi, serta mengerjakan LKM, yang disebabkan rendahnya pemahaman konsep matematika mahasiswa khususnya pada materi matriks sehingga menyebabkan mahasiswa belum mampu memecahkan masalah matematika yang lebih kompleks, yang menuntut kemampuan berpikir kritis, dan mahasiswa mengalami masalah dalam melakukan pemecahan masalah, menerapkan dalam konteks lebih luas, dan dalam konteks kehidupan sehari-hari.

Berdasarkan hasil wawancara kepada dosen pengajar matakuliah matematika teknik dasar dan pengalaman penulis sendiri selaku salah satu tim dosen pengampu mata kuliah matematika teknik dasar, bahwa pada saat perkuliahan mahasiswa cenderung bersikap pasif, kurangnya aktivitas mahasiswa dalam memperhatikan dan mendengarkan penjelasan dosen, bertanya, berdiskusi menyatakan pendapatnya, serta malas mengerjakan LKM, mahasiswa cenderung lebih banyak diam pada saat dosen mengajukan pertanyaan, hanya sebagian mahasiswa yang mampu menjawab pertanyaan dosen dan hanya sebagian mahasiswa yang rajin dalam mengerjakan LKM, sehingga menimbulkan kurangnya interaksi antara dosen dan mahasiswa.

Pada saat perkuliahan berlangsung terlihat bahwa sikap ilmiah yang dimiliki mahasiswa tersebut juga masih kurang, seperti sikap ingin tahu, kerjasama, ketelitian, tanggung jawab, berfikir kritis dan percaya diri sewaktu belajar. Penggunaan pola pembelajaran yang belum tepat dapat menyebabkan mahasiswa memiliki sedikit pengetahuan dan tidak mampu menemukan sendiri konsep-konsep pembelajaran, selain itu mahasiswa menjadi kurang teliti dalam mengerjakan tugas yang diberikan dosen serta rendahnya rasa tanggung jawab mahasiswa terhadap kegiatan pembelajaran yang dilakukan. Sebenarnya di dalam proses pembelajaran dosen sudah berusaha mengadakan perbaikan, baik dalam membuat persiapan mengajar maupun dalam proses pembelajaran seperti mengingatkan kembali materi yang lalu sebelum memulai pelajaran, memberikan tugas rutin kemudian membahas pada pertemuan berikutnya, menerapkan belajar kelompok namun hanya beberapa orang mahasiswa saja yang terlibat dalam mengerjakan tugas kelompok dan memberikan ulangan perbaikan bagi mahasiswa yang bernilai rendah, namun usaha tersebut belum berhasil seperti yang diharapkan.

Sejalan dengan fakta/permasalahan tersebut diatas, Soegiono (1984) dalam Fauziah, Parta, dan Rahardjo (2016 : 1722) menyatakan bahwa kesulitan-kesulitan peserta didik dalam menyelesaikan soal-soal matematika adalah sebagai berikut:

a. Ketidakmampuan peserta didik dalam penguasaan konsep secara benar. Ketidakmampuan peserta didik dalam penguasaan konsep secara benar ini banyak dialami peserta didik yang belum sampai proses berpikir abstrak, yaitu masih dalam taraf berpikir konkret. Sementara itu, konsep-konsep dalam matematika diajarkan secara abstrak yang tersusun secara deduktif aksiomatis, ini tentunya menyebabkan peserta didik kurang menguasai dalam memahami konsep-konsep tersebut.

b. Ketidakmampuan menggunakan data. Bahwa dalam suatu soal tentunya diberikan data-data dari suatu permasalahan. Namun, banyak peserta didik yang tidak mampu menggunakan data mana yang seharusnya dipakai. Kesulitan ini sangat dipengaruhi oleh pengetahuan peserta didik tentang konsep ataupun istilah-istilah dalam soal.

c. Ketidakmampuan mengartikan bahasa matematika. Bahasa matematika merupakan bahasa simbol yang padat, akurat, abstrak dan penuh arti. Kebanyakan peserta didik hanya mampu menuliskan atau mengucapkan, tetapi tidak dapat menggunakannya. Indikator kesulitan ini adalah kesalahan menginterpretasikan simbol-simbol, grafik, tabel dalam matematika.

d. Ketidakcermatan dalam melakukan operasi hitung. Untuk mengerjakan soalsoal matematika diperlukan konsentrasi yang tinggi karena banyak manipulasi rumus-rumus dan banyaknya operasi hitung dalam melakukan operasi terhadap rumus-rumus. peserta didik dituntut untuk cermat terhadap kesalahankesalahan yang dapat terjadi, baik disengaja dilakukan ataupun tanpa disadari telah dilakukan oleh peserta didik. Hal ini menunjukkan bahwa peserta didik dapat mengalami kesulitan karena ketidakcermatan terhadap operasi hitung yang telah dilakukan. 


\section{Enny Keristiana Sinaga - Syafiatun Siregar - Asri Lubis}

e. Ketidakmampuan dalam menarik kesimpulan. Kesimpulan merupakan hasil akhir dari suatu soal pembuktian, suatu pembuktian haruslah disusun secara logis dan sistematis berdasarkan teoremateorema, konsep-konsep atau definisidefinisi yang telah dipahami, sehingga kesimpulan yang dibuat berlaku untuk umum dan juga memperjelas dari pembuktian tersebut. Peserta didik yang mengalami kesulitan dalam menyimpulkan untuk pembuktian pada soal banyak disebabkan oleh kurangnya penguasaan terhadap konsep.

Berdasarkan kesulitan-kesulitan yang dialami peserta didik dalam menyelesaikan soal-soal matematika tersebut menunjukkan pentingnya pemahaman konsep-konsep yang terdapat dalam matematika. Oleh karena itu, memahami konsep sebelumnya dalam matematika merupakan prasyarat untuk memahami konsep selanjutnya, sehingga implikasi terhadap belajar matematika haruslah bertahap dan berurutan secara sistematis serta didasarkan pada pengalaman belajar yang telah lalu.

Konsep adalah adalah gagasan atau abstraksi yang dibentuk untuk menyederhanakan lingkungan disekitar kita. Konsep dibentuk dengan penggolongan hasilhasil pengamatan dalam suatu kategori tertentu.. penggolongan didasarkan pada kesamaan dan mengesampingkan perbedaanperbedaan. Konsep disebut abstraksi karena konsep menyatakan proses abstraksi (penggambaran) pada berbagai pengalaman aktual kita. Konsep tersusun sebagai penggambaran mental atas pengalaman yang kita amati dan didasari oleh berbagai fakta (Depdiknas, 2005).

Dalam kaitannya dengan mengajar dan belajar, konsep memiliki arti penting yang mengacu pada tata cara pengetahuan dan pengalaman dikategorisasikan. Belajar konsep pada dasarnya adalah meletakkan berbagai macam hal ke dalam golongan-golongan dan setelah itu mampu mengenali anggota-anggota golongan itu. Belajar konsep lebih dari sekadar menglasifikasikan berbagai aspek membentuk berbagai katagori. Belajar konsep melibatkan proses mengontruksi pengetahuan dan mengorganisasikan informasi menjadi struktur yang komprehensif dan kompleks. (Arends, 2001).

Dalam belajar matematika diperlukan pemahaman dan penguasaan materi dalam membaca simbol, tabel dan diagram yang sering digunakan dalam matematika serta struktur matematika yang kompleks, dari yang kongkrit sampai yang abstrak, apalagi jika yang diberikan adalah soal dalam bentuk cerita yang memerlukan kemampuan penerjemahan soal kedalam kalimat matemtika dengan memperhatikan maksud dari pertanyaan soal tersebut. Menurut Yustisia (2008:429), pemahaman konsep merupakan kompetensi yang ditunjukkan siswa dalam memahami konsep dan melakukan prosedur ( algoritma ) secara lues, akurat, efisien, dan tepat.

Salah satu tujuan mata pelajaran matematika dalam kurikulum 2013 yaitu bertujuan agar peserta didik memiliki kemampuan memahami konsep matematika, menjelaskan keterkaitan antar konsep, dan mengaplikasikan konsep atau algoritma, secara luwes, akurat, efisien, dan tepat. Untuk menanamkan konsep suatu materi pelajaran,biasanya sajian diberikan dari pengalaman yang suudah diketahui peserta didik menuju ke definisi formal materi tersebut. Definisi tidak diberikan dalam bentuk final/akhir, namun peserta didik mencoba merumuskan sendiri dari hasil pengalamannya dengan bahasannya sendiri (Ahsan, 1998:153). Seperti yang dikatakan sebelumnya bahwa tujuan utama pengajaran matematika adalah pencapaian transfer belajar. Maka penguasaan konsep perlu dibuktikan dengan kemampuan peserta didik untuk mengerjakan soal-soal. Dari kegiatan inilah guru/dosen dapat mengetahui kemampuan peserta didik menggunakan konsep tersebut dalam menyelesaikan soal-soal dapat mendiagnosis kesulitan peserta didiknya. Konsep dalam matematika meliputi : definisi, aksioma dan asumsi. Di dalam menyelesaikan soal-soal penguasaan konsep merupakan hal yang sangat mendasar harus dimiliki oleh peserta didik. Selama ini, hanya melihat hasil akhir dari pekerjaan peserta didik dan tidak memperhtikan kemampuan dalam pemahaman konsep. Untuk mengetahui seberapa jauh pemahaman konsep siswa terhadap materi pembelajaran yang harus dikuasainya, maka dilakukan pemahaman konsep.

Selain pemahaman konsep, sikap ilmiah juga penting dalam proses pembelajaran sebab sikap ilmiah merupakan aspek yang penting karena berpengaruh pada budi pekerti serta pembentukan karakter yang baik pada diri mahasiswa. Surajiyo (2008) menyatakan bahwa sikap ilmiah bukanlah membahas tentang tujuan ilmu, melainkan bagaimana cara mencapai suatu ilmu yang bebas dari prasangka pribadi dan dapat 


\section{Pengaruh Pembelajaran Langsung Terhadap Pemahaman Konsep Matriks Dan Sikap Ilmiah Mahasiswa Pendidikan Teknik Bangunan}

dipertanggungjawabkan secara sosial untuk melestarikan keseimbangan alam semesta ini, serta dipertanggungjawabkan kepada Tuhan. Sikap ilmiah meliputi kerendahan hati, rasa ingin tahu, terbuka, ulet, kritis, jujur, bertanggungjawab, menghargai pendapat orang lain, bersikap positif terhadap kegagalan, dan dapat bekerjasama dengan orang lain (Suastra,2009). Sikap ilmiah yang perlu dilatihkan di negara kita adalah kemampuan untuk menghargai orang lain dan keberanian peserta didik untuk menjawab pertanyaan, mengajukan pertanyaan, serta berdiskusi (Samatowa, 2010 : 87).

Berdasarkan pemaparan di atas, seyogianya mahasiswa dapat diarahkan untuk mengembangkan pemahaman konsep dan sikap ilmiah. Proses pembelajaran yang selama ini dilakukan belum mampu melatih mahasiswa untuk mengembangkan pemahaman konsep dan sikap ilmiah. Guna mengatasi permasalahan ini, maka perlu dilakukan upaya-upaya untuk menerapkan proses pembelajaran mampu melatih mahasiswa untuk mengembangkan pemahaman konsep dan sikap ilmiah. Dosen harus memilih suatu pendekatan atau strategi belajar yang benar sehingga pada saat proses belajar mengajar siswa tidak merasa bosan dan monoton. Oleh karena itu pemilihan metode pembelajaran yang tepat adalah salah satu unsur yang menentukan keberhasilan proses pencapaian tujuan pembelajaran. Salah satu strategi pembelajaran yang digunakan dalam penelitian ini adalah mencoba menerapkan model pembelajaran langsung (Direct Instruction) dengan berbantuan lembar kerja mahasiswa (LKM). Model pembelajaran langsung adalah salah satu pendekatan mengajar yang dirancang khusus untuk mengembangkan belajar peserta didik yang berkaitan dengan pengetahuan deklaratif dan pengetahuan prosedural yang dapat diajarkan dengan pola selangkah demi selangkah (Kardi dan Nur, 2000: 5).

Dalam menerapkan model pembelajaran langsung dosen harus mendemonstrasikan pengetahuan atau keterampilan yang akan dilatihkan kepada siswa secara langkah demi langkah. Pada kenyataannya, peran dosen dalam pembelajaran sangat dominan, maka dosen dituntut agar dapat menjadi seorang model yang menarik bagi mahasiswa. Selain itu, seorang dosen juga dapat mengkaitkan dengan diskusi kelas dan belajar kooperatif. Sebagaimana dikemukakan oleh Kardi (dalam Sofiyah 2010:21) bahwa seorang dosen dapat menggunakan Direct Instruction untuk mengajarkan materi atau keterampilan baru dengan diskusi kelompok. Hal tersebut bertujuan untuk melatih peserta didik berpikir, menerapkan keterampilan yang baru diperolehnya, serta membangun pemahamannya sendiri tentang materi pembelajaran.

Hasil penelitian Desri, Cesaria, dan Estetikasari (2017) memberikan bukti empiris bahwa pemahaman konsep matematis siswa dengan menerapkan model pembelajaran langsung dengan teknik Spotlight lebih baik dari pada pemahaman konsep matematis siswa dengan menerapkan pembelajaran konvensional. Sementara itu, hasil penelitian Hastuti (2013) menunjukkan bahwa pemahaman konsep matematika siswa yang belajar menggunakan model pembelajaran langsung dengan teknik nominal group lebih baik daripada pemahaman konsep matematika siswa yang belajar menggunakan pembelajaran konvensional.

Pengalaman belajar mahasiswa dalam pembelajaran langsung melatih mahasiswa berpikir, menerapkan keterampilan yang baru diperolehnya, serta membangun pemahamannya sendiri tentang materi pembelajaran sehingga dalam proses pembelajaran menjadi aktif. Dalam model pembelajaran langsung terdapat lima (5) fase yang sangat penting, yaitu fase orientasi, presentasi/ demonstrasi, latihan terstruktur, latihan terbimbing, dan latihan mandiri. Dengan demikian, penerapan model pembelajaran langsung mampu meningkatkan penguasaan mahasiswa terhadap materi yang diajarkan oleh dosen dan juga mampu menumbuhkan sikap ilmiah seperti sikap jujur, objektif, terbuka, ulet, kritis, bertanggung jawab, dan dapat bekerjasama dengan orang lain, serta memperoleh pengalaman dalam menerapkan metode ilmiah.

Oleh karena itu, pemilihan model pembelajaran langsung ini diharapkan dapat mempengaruhi proses belajar mahasiswa sehingga diharapkan konsep matematika khususnya pada materi matriks yang diajarkan oleh dosen akan mudah dipahami oleh siswa, dan berdampak positif pada hasil belajar dan sikap ilmiah mahasiswa. Hal inilah yang menjadi alasan peneliti untuk melakukan penelitian, supaya dapat mengembangkan, menerapkan model pembelajaran langsung dalam bidang mata kuliah matematika di Program Studi PTB Universitas Negeri Medan. 


\section{Enny Keristiana Sinaga - Syafiatun Siregar - Asri Lubis}

Berdasarkan latar belakang, maka dapat dirumuskan permasalahan sebagai berikut :

1. Apakah terdapat perbedaan penguasaan konsep matriks antara mahasiswa yang dibelajarkan dengan model pembelajaran langsung dan mahasiswa yang dibelajarkan dengan model pembelajaran konvensional?

2. Apakah terdapat perbedaan sikap ilmiah antara mahasiswa yang dibelajarkan dengan model pembelajaran langsung dan mahasiswa yang dibelajarkan dengan model pembelajaran konvensional?

3. Apakah terdapat perbedaan penguasaan konsep matriks dan sikap ilmiah antara mahasiswa yang dibelajarkan dengan model pembelajaran langsung dan mahasiswa yang dibelajarkan dengan model pembelajaran konvensional?

Berdasarkan latar belakang dan permasalahan- permasalahan yang telah dirumuskan sebelumnya maka tujuan penelitian ini adalah :

1. Mendeskripsikan dan menganalisis perbedaan penguasaan konsep matriks antara mahasiswa yang dibelajarkan dengan model pembelajaran langsung dan mahasiswa yang dibelajarkan dengan model pembelajaran konvensional.

2. Mendeskripsikan dan menganalisis perbedaan sikap ilmiah antara mahasiswa yang dibelajarkan dengan model pembelajaran langsung dan mahasiswa yang dibelajarkan dengan model pembelajaran konvensional.

3. Mendeskripsikan dan dan menganalisis perbedaan penguasaan konsep matriks dan sikap ilmiah antara mahasiswa yang dibelajarkan dengan model pembelajaran langsung dan mahasiswa yang dibelajarkan dengan model pembelajaran konvensional.

\section{Metodologi}

Penelitian ini menggunakan pendekatan penelitian kuantitatif dengan metode penelitian eksperimen. Adapun jenis eksperimen pada penelitian ini adalah eksperimen semu (quasieksperiment) dengan desain pretest-postest control group design yang digambarkan sebagai berikut

\begin{tabular}{ccc}
$\mathrm{O}_{1}$ & $\mathrm{X}$ & $\mathrm{O}_{2}$ \\
\hline $\mathrm{O}_{3}$ & & $\mathrm{O}_{4}$
\end{tabular}

Gambar 1. Desain Penelitian (Diadaptasi dari Sugiyono, 2010)

Keterangan

$X$ : Perlakuan

$\mathrm{O}_{1}$ : Pretest mahasiswa yang dibelajarkan dengan menggunakan model pembelajaran langsung

$\mathrm{O}_{2}$ : Posttest mahasiswa yang dibelajarkan dengan menggunakan model pembelajaran langsung

$\mathrm{O}_{3}$ : Pretest mahasiswa yang dibelajarkan dengan menggunakan model pembelajaran konvensional

$\mathrm{O}_{4}$ : Posttes mahasiswa yang dibelajarkan dengan menggunakan model pembelajaran konvensional

Variabel penelitian terdiri dari variabel bebas, yaitu model pembelajaran langsung dan variabel terikat, yaitu pemahaman konsep matriks dan sikap ilmiah. Populasi dalam penelitian ini adalah seluruh mahasiswa Program Studi Pendidikan Teknik Bangunan semester 1 tahun ajaran 2017/2018 yang terdiri dari 2 kelas dengan jumlah mahasiswa sebanyak 60 orang mahasiswa. Teknik pengambilan sampel dalam penelitian ini menggunakan teknik total sampling. Menurut Sugiyono (2013:124) total sampling yaitu teknik penentuan sampel dengan cara mengambil seluruh anggota populasi sebagai responden atau sampel. Jadi sampel dalam penelitian ini adalah seluruh mahasiswa Program Stidi PTB Universitas Negeri Medan semester 1 tahun ajaran 2017/2018 yang berjumlah 60 orang.

Instrumen penelitian terdiri atas perangkat pembelajaran (RPP, LKM, dan Buku Mahasiswa) dan instrumen pengumpulan data (tes pemahaman konsep dan angket sikap ilmiah). Perangkat pembelajaran digunakan dalam pelaksanaan pembelajaran, sedangkan instrument pengumpulan data sebagai alat pengambilan data penelitian. sebelum digunakan, semua instrument tersebut dilakukan uji validasi oleh dua orang dosen sebagai validator ahli.

Data penelitian dianalisis dengan statistika dskriptif dan statistika inferensial (uji MANOVA). Analisis deskriptif diguanakan untuk mendeskripsikan nilai rata-rata skor test pemahaman konsep dan sikap ilmiah dari masing-masing model pembelajaran. Analisis menggunakan analisis gain score dengan menentukan gain score ternormalisasi dengan rumus :

$$
g=\frac{s_{\text {post }}-S_{\text {pre }}}{S_{\text {Maks }}-S_{\text {pre }}}
$$

(Sumber : Hake, 1999)

Keterangan

G : Gain yang dinormalisasi (N- 


$\begin{array}{lll} & & \text { Gain) } \\ S_{\text {maks }} & : & \text { Skor maksimum (ideal) dari } \\ & \text { pretest dan posttest } \\ \mathrm{S}_{\text {post }} & : & \text { Skor posttest } \\ \mathrm{S}_{\text {pre }} & : & \text { Skor pretest }\end{array}$

Tingkat perolehan score ternormalisasi dikategorikan kedalam tiga kategori, yaitu :

$\begin{array}{lll}\text { Gain-tinggi } & =\mathrm{N} \text {-gain }>0.7 \\ \text { Gain-sedang } & = & 0.7 \geq \mathrm{N} \text {-gain } \geq 0.3 \\ \text { Gain-rendah } & = & \mathrm{N} \text {-gain }<0.3\end{array}$

Uji MANOVA digunakan untuk pengujian terhadap hipotesis yang telah dirumuskan pada taraf signifikansi 5\%. Uji multivariat atau pengujian antar subjek dilakukan terhadap angka signifikansi dari nilai $\mathrm{F}$ statistik Pillai's Trace, Wilks' Lambda, Hotelling' Trace, Roy's Largest Root (Candiasa, 2010). Angka signifikansi lebih kecil dari 0,05 berarti $\mathrm{H}_{0}$ ditolak yang artinya terdapat perbedaan variabel dependen antar kelompok menurut sumber.Sebelum dilakukan Uji MANOVA, terlebih dahulu dilakukan uji prasyarat, yaitu uji normalitas, homogenitas, dan uji kolinearitas.

Hipotesis penelitian ini, yaitu : (1) terdapat perbedaan pemahaman konsep matriks antara mahasiswa yang dibelajarkan dengan model pembelajaran langsung dan mahasiswa yang dibelajarkan dengan model pembelajaran konvensional, (2) terdapat perbedaan sikap ilmiah antara mahasiswa yang dibelajarkan dengan model pembelajaran langsung dan mahasiswa yang dibelajarkan dengan model pembelajaran konvensional, (3) terdapat perbedaan pemahaman konsep matriks dan sikap ilmiah antara mahasiswa yang dibelajarkan dengan model pembelajaran langsung dan mahasiswa yang dibelajarkan dengan model pembelajaran konvensional.

\section{Hasil dan Pembahasan}

Varibel terikat dalam penelitian ini adalah perbedaan gain score pemahaman konsep dan sikap ilmiah mahasiswa siswa sebagai hasil perlakuan antara penerapan model pembelajaran langsung dan model pembelajaran konvensional. Penghitungan ukuran sentral (mean, median, modus) dan ukuran penyebaran data (standar deviasi) untuk data gain score pemahaman konsep dan gain score sikap ilmiah disajikan pada Tabel 1.

Tabel 1. Rekapitulasi Data Hasil penelitian

\begin{tabular}{lcccc}
\hline \multirow{2}{*}{ Statistik } & \multicolumn{2}{c}{$\begin{array}{l}\text { Model Pembelajaran } \\
\text { Langsung }\end{array}$} & \multicolumn{2}{c}{$\begin{array}{l}\text { Model } \\
\text { Pembelajaran } \\
\text { Konvensional }\end{array}$} \\
\cline { 2 - 5 } & $\begin{array}{l}\text { Pemaha } \\
\text { man } \\
\text { Konsep }\end{array}$ & $\begin{array}{l}\text { Sikap } \\
\text { Ilmiah }\end{array}$ & $\begin{array}{l}\text { Pemaha } \\
\text { man } \\
\text { Konsep }\end{array}$ & $\begin{array}{l}\text { Sikap } \\
\text { Ilmiah }\end{array}$ \\
\hline Mean & 0,64 & 0,50 & 0,46 & 0,39 \\
Median & 0,64 & 0,48 & 0,47 & 0,40 \\
Modus & 0,64 & 0,25 & 0,43 & 0,33 \\
Simpang & 0,08 & 0,17 & 0,12 & 0,12 \\
an Baku & & & & \\
\hline
\end{tabular}

Berdasarkan Tabel 1 diperoleh informasi bahwa rata-rata pemahaman konsep mahasiswa yang dibelajarkan dengan model pembelajaran langsung $(0,64)$ berada pada kualifikasi gain sedang lebih besar jika dibandingkan dengan rata-rata pemahaman konsep mahasiswa yang dibelajaran dengan model pembelajaran konvensional $(0,46)$ berada pada kualifikasi sedang. Untuk data sikap ilmiah mahasiswa yang dibelajarkan dengan model pembelajaran langsung $(0,50)$ berada pada kualifikasi gain sedang lebih besar jika dibandingkan dengan rata-rata sikap ilmiah mahasiswa yang dibelajaran dengan model pembelajaran konvensional $(0,39)$ berada pada kualifikasi sedang.

Sebelum dilakukan uji hipotesis dengan metode statistik tersebut, terlebih dahulu dilakukan uji asumsi sebagai prasyarat uji hipotesis, yaitu uji normalitas sebaran data, uji homogenitas, dan uji interkorelasi variabel terikat. Uji normalitas sebaran data dimaksudkan untuk meyakinkan bahwa sampel benar-benar berasal dari populasi yang berdistribusi normal sehingga pengujian hipotesis dengan MANOVA bisa dilakukan.

Uji normalitas data dalam penelitian ini menggunakan statistik Kolmogorov-Smirnov. Berdasarkan pengujian normalitas sebaran data diperoleh nilai statistik kolmorov-smornov 0,200 untuk data pemahaman konsep model pembelajaran langsung; 0,200 untuk data sikap ilmiah model pembelajaran langsung; 0,181 untuk data pemahaman konsep pembelajaran konvensional; dan 0,200 untuk data sikap ilmiah model pembelajaran konvensional. Nilai statistik kolmogorov-smirnov tersebut memiliki taraf signifikansi yang lebih besar dari 0,05 sehingga dapat disimpulkan data gain score pemahaman konsep dan sikap ilmiah mahasiswa berasal dari sampel yang berdistribusi normal.

Homogenitas varians diuji dengan menggunakan Levine's Test. Uji ini bertujuan untuk mengukur apakah sebuah kelompok 


\section{Enny Keristiana Sinaga - Syafiatun Siregar - Asri Lubis}

data memiliki varian yang sama di antara anggota kelompok tersebut dan untuk meyakinkan bahwa perbedaan yang terjadi pada uji hipotesis benar-benar terjadi sebagai akibat perbedaan antar kelompok. Berdasarkan hasil uji homogenitas varians diperoleh nilai levene statistik sebesar 0,096 untuk data pemahaman konsep dan 0,152 untuk data sikap ilmiah. Nilai levene statistik memiliki taraf signifikansi lebih besar dari 0,05 sehingga dapat disimpulkan data pemahaman konsep dan sikap ilmiah adalah homogen.

Uji kolinieritas dilakukan untuk mengetahui apakah terdapat hubungan yang cukup tinggi atau tidak antara variabel pemahaman konsep dengan variabel sikap ilmiah siswa. Jika tidak terdapat hubungan yang cukup tinggi, berarti tidak ada aspek yang sama diukur pada variabel tersebut, dengan demikian analisis dapat dilanjutkan. Teknik yang digunakan untuk menentukan kolinearitas adalah dengan korelasi product moment. Berdasarkan hasil pengujian kolinieritas diperoleh nilai korelasi $\left(\mathrm{r}_{\mathrm{y} 1 \mathrm{y} 2}\right)$ antara sesama variabel sebesar 0,114 lebih kecil dari 0,8 atau nilai signifikansi (sig.2-tailed) $=0.386>$ $\alpha / 2=0.025$. Ini berarti antara sesama variabel terikat tidak terjadi korelasi yang sangat kuat. Bertitik tolak dari hasil uji normalitas, homogenitas data, dan uji kolinearitas data, dapat dikatakan bahwa persyaratan untuk pengujian hipotesis dengan Manova dapat dipenuhi. Oleh karena uji prasyarat analisis sudah terpenuhi maka pengujian hipotesis dapat dilakukan dengan Manova. Pengujian masing-masing hipotesis penelitian untuk masing-masing variabel bebas dapat dijelaskan sebagai berikut.

Pengujian hipotesis pertama diperoleh hasil bahwa terdapat perbedaan pemahaman konsep antara mahasiswa yang dibelajarkan dengan model pembelajaran langsung dengan mahasiswa yang dibelajarkan dengan model pembelajaran konvensional. Hasil ini tampak dari nilai $\mathrm{F}_{\text {hitung }}(48,757)$ lebih besar dari $\mathrm{F}_{\text {tabel }}=$ $\mathrm{F}_{2 ; 27}(3,35)$. Sedangkan, pengujian hipotesis kedua diperoleh hasil bahwa terdapat perbedaan sikap ilmiah antara mahasiswa yang dibelajarkan dengan model pembelajaran langsung dengan mahasiswa yang dibelajarkan dengan model pembelajaran konvensional. Hasil ini tampak dari nilai $F_{\text {hitung }}(8,329)$ lebih besar dari $F_{\text {tabel }}=F_{2 ; 27}(3,35)$. Selanjutnya pengujian hipotesis ketiga diperoleh hasil bahwa terdapat perbedaan pemahaman konsep dan sikap ilmiah antara mahasiswa yang dibelajarkan dengan model pembelajaran langsung dengan mahasiswa yang dibelajarkan dengan model pembelajaran konvensional. Hasil ini tampak dari nilai-nilai statistik Pillai's Trace, Wilks' Lambda, Hotelling's Trace, Roy's Largest Root menunjukkan nilai $\mathrm{F}_{\text {hitung }}=32,746$ dengan taraf signifikansi 0,000 kurang dari 0,05 $(p<0.05)$.

Hasil penelitian ini sejalan dengan penelitian yang pernah diakukan oleh Hastuti (2013) menunjukkan bahwa pemahaman konsep matematika siswa yang belajar menggunakan model pembelajaran langsung lebih baik daripada pemahaman konsep matematika siswa yang belajar menggunakan pembelajaran konvensional. Desri, Cesaria, dan Estetikasari (2017) menyatakan bahwa pemahaman konsep matematis siswa dengan menerapkan model pembelajaran langsung lebih baik dari pada pemahaman konsep matematis siswa dengan menerapkan pembelajaran konvensional.

Selain didukung dengan fakta empiris, penelitian ini juga didukung oleh fakta teoritis mengenai keunggulan model pembelajaran langsung dalam pencapaian pemahaman konsep jika dibandingkan dengan model pembelajaran konvensional.

Model pengajaran langsung dilandasi oleh teori belajar perilaku yang berpandangan bahwa belajar bergantung pada pengalaman termasuk pemberian umpan balik. Satu penerapan teori perilaku dalam belajar adalah pemberian penguatan. Umpan balik kepada siswa dalam pembelajaran merupakan penguatan dalam penerapan teori perilaku tersebut.

Arends (2001) menyatakan: "Direct instruction is a teacher-centered model that has five steps: establishing set, explanation and/or demonstration, guided practice, feedback, and extended practice a direct instruction lesson requires careful orchestration by the teacher and a learning environment that businesslike and task-oriented". Artinya pengajaran langsung adalah model berpusat pada guru yang memiliki lima langkah: menetapkan tujuan, penjelasan dan/atau demonstrasi, panduan praktek, umpan balik, dan perluasan praktek. Pelajaran dalam pengajaran langsung memerlukan perencanaan yang hati-hati oleh guru dan lingkungan belajar yang menyenangkan dan berorientasi tugas.

Guru/dosen yang menggunakan model pengajaran langsung tersebut bertanggung jawab dalam mengidentifikasi tujuan pembelajaran, struktur materi, dan keterampilan dasar yang akan diajarkan. Kemudian menyampaikan pengetahuan kepada siswa, memberikan 


\section{Pengaruh Pembelajaran Langsung Terhadap Pemahaman Konsep Matriks Dan Sikap Ilmiah Mahasiswa Pendidikan Teknik Bangunan}

pemodelan/demonstrasi, memberikan kesempatan pada siswa untuk berlatih menerapkan konsep/keterampilan yang telah dipelajari, dan memberikan umpan balik.

Model pengajaran langsung memberikan kesempatan mahasiswa belajar dengan mengamati secara selektif, mengingat dan menirukan apa yang dimodelkan gurunya. Oleh karena itu hal penting yang harus diperhatikan dalam menerapkan model pengajaran langsung adalah menghindari menyampaikan pengetahuan yang terlalu kompleks. Di samping itu, model pengajaran langsung mengutamakan pendekatan deklaratif dengan titik berat pada proses belajar konsep dan keterampilan motorik, sehingga menciptakan suasana pembelajaran yang lebih terstruktur.

Dalam menerapkan model pembelajaran langsung dosen harus mendemonstrasikan pengetahuan atau keterampilan yang akan dilatihkan kepada siswa secara langkah demi langkah. Pada kenyataannya, peran dosen dalam pembelajaran sangat dominan, maka dosen dituntut agar dapat menjadi seorang model yang menarik bagi mahasiswa. Selain itu, seorang dosen juga dapat mengkaitkan dengan diskusi kelas dan belajar kooperatif. Sebagaimana dikemukakan oleh Kardi (dalam Sofiyah 2010:21) bahwa seorang dosen dapat menggunakan Direct Instruction untuk mengajarkan materi atau keterampilan baru dengan diskusi kelompok. Hal tersebut bertujuan untuk melatih peserta didik berpikir, menerapkan keterampilan yang baru diperolehnya, serta membangun pemahamannya sendiri tentang materi pembelajaran.

Dengan meningkatnya kemampuan pemahaman konsep siswa melalui penerapan model pembelajaran langsung, maka kemampuan siswa dalam memecahkan masalah yang berkaitan dengan kehidupan sehari-hari menjadi lebih baik. Perubahan paradigma dalam memahami pemahaman konsep menjadi lebih nyata, yaitu perubahan pemahaman konsep siswa dari science for scientist menjadi sciencee for life. Siswa belajar tidak hanya dalam persiapan menghadapi ulangan atau ujian saja, melainkan lebih mendalam dalam belajar untuk memahami dan memecahkan permasalahan sendiri yang berhubungan dengan kehidupan yang nyata. Dengan demikian penerapan model pembelajaran langsung dalam meningkatkan pemahaman konsep siswa dan sikap ilmiah siswa, khususnya dalam pembelajaran sudah sangat tepat diterapkan

\section{$4 \quad$ Simpulan}

Berdasarkan hasil penelitian dan pembahasan, maka dapat disimpulkan sebagai berikut :

1) Terdapat perbedaan pemahaman konsep matriks antara mahasiswa yang dibelajarkan dengan model pembelajaran langsung dan mahasiswa yang dibelajarkan dengan model pembelajaran konvensional,

2) Terdapat perbedaan sikap ilmiah antara mahasiswa yang dibelajarkan dengan model pembelajaran langsung dan mahasiswa yang dibelajarkan dengan model pembelajaran konvensional,

3) Terdapat perbedaan pemahaman konsep matriks dan sikap ilmiah antara mahasiswa yang dibelajarkan dengan model pembelajaran langsung dan mahasiswa yang dibelajarkan dengan model pembelajaran konvensional.

\section{Daftar Pustaka}

Abdurrahman, Mulijono. 2009. Pendidikan Bagi Anak Berkesulitan Belajar. Jakarta. Rineka Cipta. h. 253

Arends, R. 2001. Learning to Teach. New York: Mc graw Hill Companies, Inc

Desri. Yeri Fitriani, Cesaria. Anna, Estetikasari, Dewi. 2017. Pengaruh Penerapan Model Pembelajaran Langsung dengan Teknik Spotlight Terhadap Pemahaman Konsep Matematis Siswa Kelas VIII SMPN 25 Padang. http://jim.stkip-pgrisumbar.ac.id/jurnal/download/4755 (diaekse tanggal 8 Agustus 2017)

Hake. 1999. Analyzing Change/Gain Scores. 24245 Hatteras Street, Dept, of Physics, Indiana University. USA. Woodland Hills, CA, 91367

Kardi dan Nur. 2000. Pengajaran Langsung. Surabaya: Unesa - University Press. h. 5

Suastra, IW. 2009. Pembelajaran Sains Terkini. Undiksha: Singaraja

Sugiyono. 2010. Metode Penelitian Administratif. Bandung: Alfabeta. 
Sugiyono. 2013. Metode Penelitian Pendidikan Pendekatan Kuantitatif, Kualitatif, dan $R \mathcal{E D}$. Bandung: Alfabeta.

Surajiyo. 2008. Filsafat Ilmu. Jakarta: Bumi Aksara 